\title{
Influence of Water Content on Mechanical Strength and Microstructure of Alkali-Activated Fly Ash/GGBFS Mortars Cured at Cold and Polar Regions
}

\author{
Xiaobin Wei ${ }^{1,2, *}$, Feng Ming ${ }^{1, *}$, Dongqing Li ${ }^{1}\left(\right.$, Lei Chen ${ }^{1,2} \mathbb{D}$ and Yuhang Liu ${ }^{1,2}$ \\ 1 State Key Laboratory of Frozen Soil Engineering, Northwest Institute of Eco-Environment and Resources, \\ Chinese Academy of Sciences, Lanzhou 730000, China; dqli@lzb.ac.cn (D.L.); chenlei8@lzb.ac.cn (L.C.); \\ liuyuhang1105@lzb.ac.cn (Y.L.) \\ 2 University of Chinese Academy of Sciences, Beijing 100049, China \\ * Correspondence: weixb@lzb.ac.cn (X.W.); mingfeng05@1zb.ac.cn (F.M.)
}

Received: 27 November 2019; Accepted: 27 December 2019; Published: 29 December 2019

\begin{abstract}
Negative temperature curing is a very harmful factor for geopolymer mortar or concrete, which will decrease the strength and durability. The water in the geopolymer mixture may be frozen into ice, and the water content is a crucial factor. The purpose of this paper is to explore the influence of water content on the properties of alkali-activated binders mortar cured at $-5^{\circ} \mathrm{C}$. Fly ash (FA) and ground granulated blast furnace slag (GGBFS) were used as binders. Three groups of experiments with different water content were carried out. The prepared samples were investigated through uniaxial compression strength test, Scanning electron microscopy (SEM), and X-ray diffraction (XRD) for the determination of their compressive strength, microstructural features, phase, and composition. The results indicated that, the compressive strength of samples basically maintained $25.78 \mathrm{MPa}-27.10$ $\mathrm{MPa}$ at an age of 28 days; for 90 days, the values reached $33.4 \mathrm{MPa}-34.04 \mathrm{MPa}$. The results showed that lower water content is beneficial to improving the early strength of mortar at $-5^{\circ} \mathrm{C}$ curing condition, while it has little impact on long-term strength. These results may provide references for the design and construction of geopolymer concrete in cold regions.
\end{abstract}

Keywords: geopolymer; water content; negative temperature; compressive strength; microstructure; elastic modulus

\section{Introduction}

Production process of ordinary Portland cement (OPC) not only consumes plenty of energy and natural resources, but also emits large quantities of carbon dioxide [1-3]. A host of researchers have done abundant work in search of an environmentally friendly alternative binding material. Davidovits [4,5] proposed new materials and techniques, named "geopolymer" and was treated as the most promising alternative materials to OPC. Geopolymers, generally made from materials such as metakaolin, fly ash, and ground granulated blast furnace slag (GGBFS), etc., are rich in silicon and aluminum compounds and will react under the stimulation of alkaline solution [6]. These solid wastes can be utilized, reducing $\mathrm{CO}_{2}$ emissions by $20-50 \%$, which, to some extent, can protect the environment [7]. In addition, raw materials of geopolymer are mostly by-products of industrial products with abundant reserves and low prices. Compared with OPC, geopolymers have better mechanical, chemical, thermal properties, and durability [6,8-12]. Based on the above-mentioned characteristics, geopolymer is a better option for the development of sustainable products such as building materials, fire-retardant coatings, fiber-reinforced composite materials, and fixed solutions for chemical and nuclear industrial wastes. 
However, most previous studies about the alkali-activated fly ash/GGBFS mortar and concrete were carried out by curing samples at elevated temperature or in ambient curing condition [13]. Many researchers believed that addition of GGBFS can significantly improve early and later age mechanical strength of fly ash based geopolymer concrete cured at room temperature [14,15]. Up to now, the research on the physical and mechanical properties of geopolymer concrete curing at negative temperature has not been reported.

With the social development, cleaner and energy-saving building materials are needed in cold and polar regions of the world. For example, Figure 1 shows the mean annual air temperature distribution of China in 2015 [16], and the temperature in most areas is lower than $0{ }^{\circ} \mathrm{C}$, however, many infrastructures were built in these areas, such as Qinghai-Tibet railway, Sichuan-Lasa Expressway, and Harbin Dalian high speed railway. These projects only have a very short construction period of positive temperature (above $0{ }^{\circ} \mathrm{C}$ ) every year, which will extend the entire construction period and increase the cost. If the in-situ casting geopolymer concrete with better performance can be obtained under the condition of negative temperature curing, the construction period will be shortened and the cost will be saved.

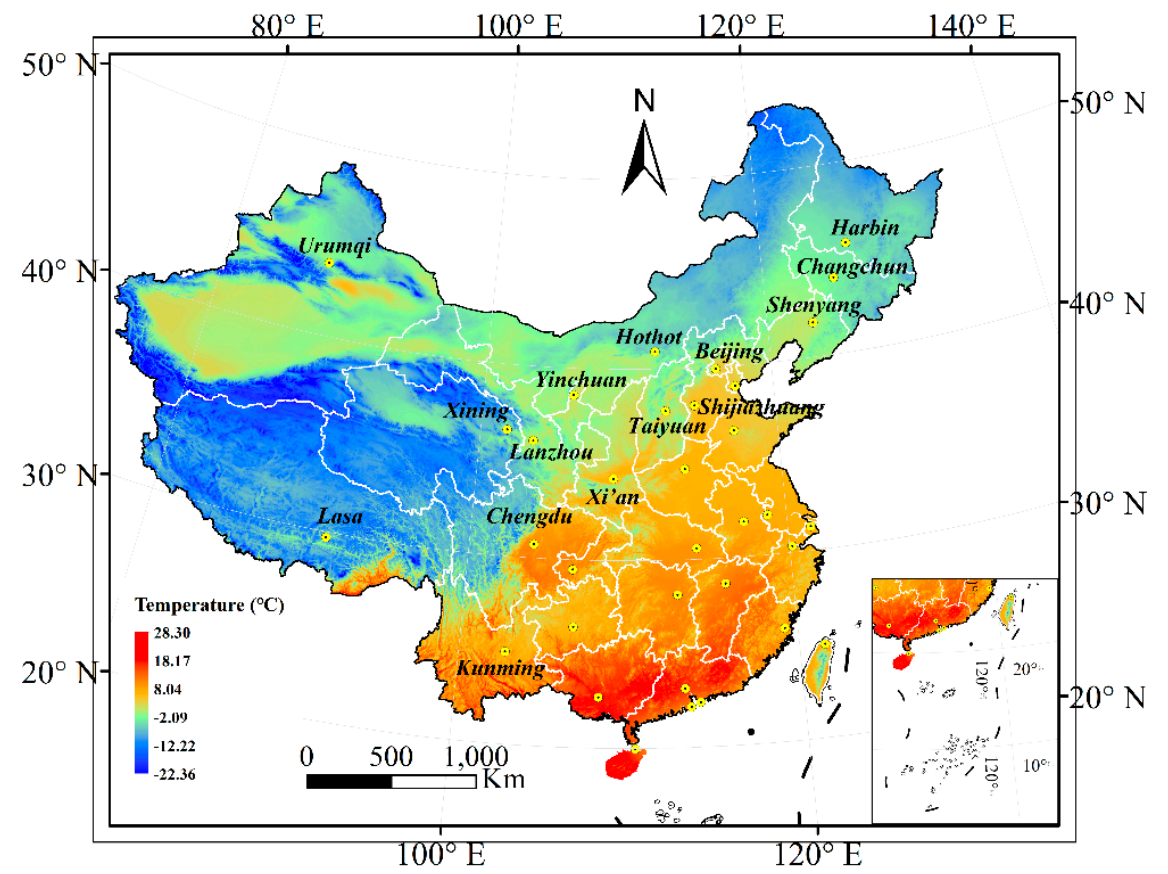

Figure 1. The mean annual air temperature distribution of China in 2015 [16].

In the OPC hydration process, water is a paramount component participating in chemical reaction to produce hydration products, which makes concrete or mortar have good workability. The role of water in the depolymerization, dissolution, polymerization, and hardening of geopolymer has been explored by some scholars. Weng et al. [17] considered that water was the transport medium of aluminosilicate dissolution, ions transfer, tetrahedral compounds hydrolysis, and tetrahedral units polymerization. Aliabdo et al. [18] revealed that the addition of water improved the workability of mixture, but reduced other properties of geopolymer concrete. The optimum additional water content was $30 \mathrm{~kg} / \mathrm{m}^{3}$, which has little effect on properties of geopolymer. It was found that using extra water to improve the workability of fly ash geopolymer had higher strength than adding superplasticizer [19]. Literature [20] reported that the lower the initial water content, the higher the strength growth rate of geopolymer cured at room temperature from 7 days to 14 days, in addition, the strength growth rate of heat-cured specimens did not seem to be affected by the lower initial water content. However, hydration process of geopolymer cured at negative temperature will be more complex, water content is still a vital factor. 
In view of the above-mentioned background, it is necessary to explore the characteristics of geopolymer cured at negative temperature. In this paper, the influence of water content was investigated to see whether it could be beneficial on improving the properties of fly ash and GBBFS-based geopolymer mortar at negative temperature cured. A series of laboratory tests were carried out by testing the strength, observing the microstructure characteristics and identifying the formation of minerals. $-5^{\circ} \mathrm{C}$ was selected as a representative curing temperature to simulate weather and construction conditions in cold and polar regions. These characteristics were also compared with the research results of ambient-cured specimens in previous literature.

\section{Materials and Methods}

\subsection{Raw Materials}

In this study, a low calcium fly ash (Class F) was obtained from a thermal power plant in Yulin city, Shanxi province, China. GGBFS was used as the major ingredient [21]. The initial particle distribution curves of the fly ash (FA) and GGBFS are shown in Figure 2, the average particle size is $34.46 \mu \mathrm{m}$ and $8.75 \mu \mathrm{m}$, respectively. The chemical components of FA and GGBFS are shown in Table 1, which were determined by a Bruker S8 TIGER Series 2 X-ray fluorescence (XRF, Bruker Corporation, Karlsruhe, Germany) apparatus. The chemical component of FA is vital important to the test results [22]. Moreover, Figure 3 exhibited XRD patterns of the FA and GGBFS, respectively, which were conducted on a Bruker D8 ADVANCE apparatus. The equipment mentioned above is produced by Bruker company in Germany. XRD patterns clearly showed the presence of quartz $\left(\mathrm{SiO}_{2}\right)$, mullite $\left.\left(3 \mathrm{Al}_{2} \mathrm{O}_{3} \cdot 2 \mathrm{SiO}\right)_{2}\right)$, calcite $\left(\mathrm{CaCO}_{3}\right)$, and akermanite $\left(\mathrm{Ca}_{2} \mathrm{Mg}\left(\mathrm{Si}_{2} \mathrm{O}_{7}\right)\right)$ crystalline phase, which were indicated by sharp peaks.



Figure 2. Initial particle distribution curves of FA and GGBFS.

Table 1. Chemical components of fly ash (FA) and ground granulated blast furnace slag (GGBFS) by $\mathrm{X}$-ray fluorescence (XRF) analysis.

\begin{tabular}{ccc}
\hline Chemical Composition (wt \%) & Fly Ash & GGBFS \\
\hline $\mathrm{SiO}_{2}$ & 51.70 & 28.57 \\
$\mathrm{Al}_{2} \mathrm{O}_{3}$ & 15.68 & 13.55 \\
$\mathrm{CaO}$ & 9.96 & 30.44 \\
$\mathrm{Fe}_{2} \mathrm{O}_{3}$ & 19.06 & 2.92 \\
$\mathrm{MgO}$ & 1.48 & 9.80 \\
$\mathrm{Na} O$ & 0.57 & 0.59 \\
$\mathrm{~K}_{2} \mathrm{O}$ & 1.04 & 0.34 \\
$\mathrm{~S}$ & 0.27 & 0 \\
other & 0.24 & 13.79 \\
\hline
\end{tabular}




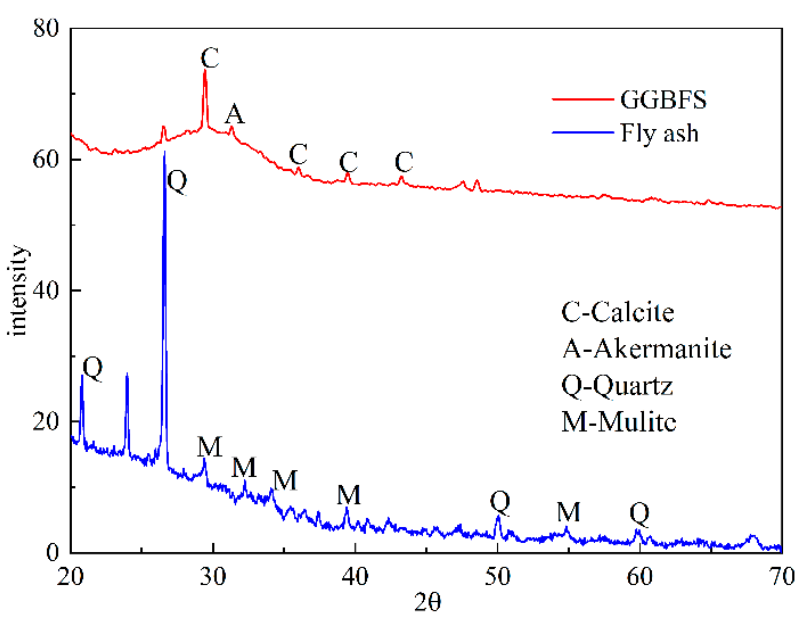

Figure 3. XRD patterns of FA and GGBFS.

Sodium hydroxide $(\mathrm{NaOH})$ and sodium silicate $\left(\mathrm{Na}_{2} \mathrm{SiO}_{3}\right)$ solution were selected as alkaline activator after comparing available activators [23].The modulus of sodium silicate was 3.306 with chemical composition of $26.65 \% \mathrm{SiO}_{2}, 8.32 \% \mathrm{Na}_{2} \mathrm{O}$, and $65.03 \% \mathrm{H}_{2} \mathrm{O}$. The $\mathrm{NaOH}$ solution was formulated with $60 \mathrm{~g}$ tap water and $28.80 \mathrm{~g} \mathrm{NaOH}$ solid particles. The purity of sodium hydroxide pellet was more than $96 \%$. The prepared concentration of sodium hydroxide solution was remained constant $12 \mathrm{~mol} / \mathrm{L}$ in all mixtures.

The standard sand was obtained from an ISO Standard Sand Co., Ltd. (Xiamen) of China. Sodium tetraborate $\left(\mathrm{Na}_{2} \mathrm{BO}_{7} \cdot \mathrm{H}_{2} \mathrm{O}\right)$ was used as retarder. The content of analytic pure sodium tetraborate was higher than $99.5 \%$. A polycarboxylate based superplasticizer and an antifreeze agent were used in the samples. These additives were used to improve the workability of geopolymer mortar mixture.

\subsection{Mixture Proportions}

The mixes that used in this paper were designed and listed in Table 2. All mixtures contain the same amount of fly ash, GGBFS, and activator solution, except for the additional water content. The only variable was the additional water content. It needed to be emphasized that the "water content" here refers to the total amount of $\mathrm{H}_{2} \mathrm{O}$ brought from additional water, $\mathrm{NaOH}$ solution, and sodium silicate solution. The water content in $\mathrm{NaOH}$ solution and sodium silicate solution was $60 \mathrm{~g}$ and 78.04 $\mathrm{g}(120 \mathrm{~g} \times 65.03 \%)$, respectively. Superplasticizer $1 \mathrm{~g}(0.22 \mathrm{wt} \%$ of binder $)$, retarder $5 \mathrm{~g}(1.11 \mathrm{wt} \%$ of binder), and antifreeze agent $10 \mathrm{~g}$ ( $2.22 \mathrm{wt} \%$ of binder) were added to the mixture as additives, respectively. The addition amount of these additives was the ideal addition amount determined by repeated tests, which can ensure that the mortar has desired workability and the moisture in it was not frozen at temperature of $-5^{\circ} \mathrm{C}$.

Table 2. Details of geopolymer mortar mix proportions.

\begin{tabular}{cccccccccc}
\hline \multirow{2}{*}{ Mix No. } & \multicolumn{8}{c}{ Mortar Mixture Quantity (Unit: g) } \\
\cline { 2 - 9 } & Fly Ash & GGBFS & Additional Water & Sand & SH $^{\mathbf{1}}$ & SS $^{\mathbf{2}}$ & SP $^{\mathbf{3}}$ & BR $^{\mathbf{4}}$ & AF $^{\mathbf{5}}$ \\
\hline T1 & 225 & 225 & 50 & 1350 & 88.8 & 120 & 1 & 5 & 10 \\
T2 & 225 & 225 & 20 & 1350 & 88.8 & 120 & 1 & 5 & 10 \\
T3 & 225 & 225 & 0 & 1350 & 88.8 & 120 & 1 & 5 & 10 \\
\hline
\end{tabular}

${ }^{1} \mathrm{NaOH}$ solution; ${ }^{2} \mathrm{Na}_{2} \mathrm{SiO}_{3}$ solution; ${ }^{3}$ Superplasticizer; ${ }^{4}$ Borax; ${ }^{5}$ Antifreeze agent.

The parameter "Water-to-Binder Mass Ratio" (W/B) was calculated. W/B ratio and critical molar ratios of all mixtures were shown in Table 3. The $\mathrm{Si} / \mathrm{Al}$ ratio and $\mathrm{Na}_{2} \mathrm{O} / \mathrm{SiO}_{2}$ ratio were the most important parameters in many literatures [4,6,24-26]. The Si/Al ratio of each group was 2.75 , which meant that the three dimensional silico-aluminate structures produced may be the Poly(sialate-siloxo) 
type (-Si-O-Al-O-Si-O-) and Poly(sialate-disiloxo) type (-Si-O-Al-O-Si-O-Si-O-) according to previous research results [4,5]. Davidovits believed that these two structures can achieve desired mechanical strength. Molar ratio of $\mathrm{H}_{2} \mathrm{O} / \mathrm{Na}_{2} \mathrm{O}$ was another vital parameter for the change of water content. Generally speaking, on the premise of desired workability of mixtures, reducing water consumption as much as possible was conducive to improving the mechanical properties and durability of geopolymer concrete. The mass ratio of $\mathrm{Na}_{2} \mathrm{SiO}_{3}$ solution to $\mathrm{NaOH}$ solution (SS/SH) was 1.35, and alkaline solution constituted $46.4 \%$ of the total binder by mass.

Table 3. Critical molar ratios and water/binder of all mixtures.

\begin{tabular}{ccccc}
\hline \multirow{2}{*}{ Mix No. } & \multirow{2}{*}{ Water/Binder } & \multicolumn{3}{c}{ Molar Ratio } \\
\cline { 3 - 5 } & & $\mathbf{S i} / \mathbf{A l}$ & $\mathbf{N a}_{\mathbf{2}} \mathbf{O} / \mathbf{S i O}_{\mathbf{2}}$ & $\mathbf{H}_{\mathbf{2}} \mathbf{O} / \mathbf{N a}_{\mathbf{2}} \mathbf{O}$ \\
\hline $\mathrm{T} 1$ & 0.42 & 2.75 & 0.09 & 51.44 \\
$\mathrm{~T} 2$ & 0.35 & 2.75 & 0.09 & 43.23 \\
$\mathrm{~T} 3$ & 0.31 & 2.75 & 0.09 & 37.76 \\
\hline
\end{tabular}

\subsection{Mixing, Specimen Preparation, and Curing}

The first step was activator solution preparation. The temperature of sodium hydroxide solution would increase due to the large amount of heat generated when sodium hydroxide solid particles were dissolved in water. Some researches premixed the $\mathrm{NaOH}$ solutions until the solution reached room temperature within $24 \mathrm{~h}$ [27], and others [28] considered that the activator mixed with sodium silicate and sodium hydroxide powder has more advantages than that in liquid form. In this study, the activator was still in the form of liquid solution, the purpose of this operation was to eliminate the unreliability of test results caused by heat originated from sodium hydroxide particles dissolving. The $\mathrm{NaOH}$ solution was premixed until its temperature reached room temperature.

The steel mold consisted of a horizontal groove, which can simultaneously form six specimens of $40 \mathrm{~mm} \times 40 \mathrm{~mm} \times 40 \mathrm{~mm}$ in size. Before the mortar was put into the mold, a thin layer of demolding agent was coated on the inner surface of the mold to facilitate demolding and ensure the smooth and intact surface of the samples.

The complete process of samples preparation exhibited in Figure 4. Mortar ingredients were mixed in a laboratory cement mortar mixer (JJ-5). After all the components were accurately weighed, the binders (fly ash and GGBFS) and other dry ingredients were thoroughly mixed in the mixing pan for two minutes. $\mathrm{NaOH}$ solution, $\mathrm{Na}_{2} \mathrm{SiO}_{3}$ solution, and additional water were added to the mixture in turn, and then stirred continuously for four minutes. The molds were cast with geopolymer mortars and vibrated compactly on a shaking table. All the above operation steps were carried out at room temperature (about $20^{\circ} \mathrm{C}$ ). The initial setting of mortar was completed about $45 \mathrm{~min}$. After the vibration compaction, the specimens were packed in a sealed bag and immediately put into a freezer and cured at constant temperature of $-5^{\circ} \mathrm{C}$. After $24 \mathrm{~h}$ of casting, all specimens were demolded and cured continuously at $-5^{\circ} \mathrm{C}$ in the freezer until the performance of different ages $(3 \mathrm{~d}, 7 \mathrm{~d}, 28 \mathrm{~d}, 90 \mathrm{~d})$ were tested. Owing to the small size of the samples, the temperature of the samples placed into the freezer was lowered to $-5{ }^{\circ} \mathrm{C}$ in a short time. However, temperature was a vital factor in the chemical reaction of geopolymer. The purpose of this operation process was to simulate the worst situation that geopolymer concrete may encounter on-site casting. 


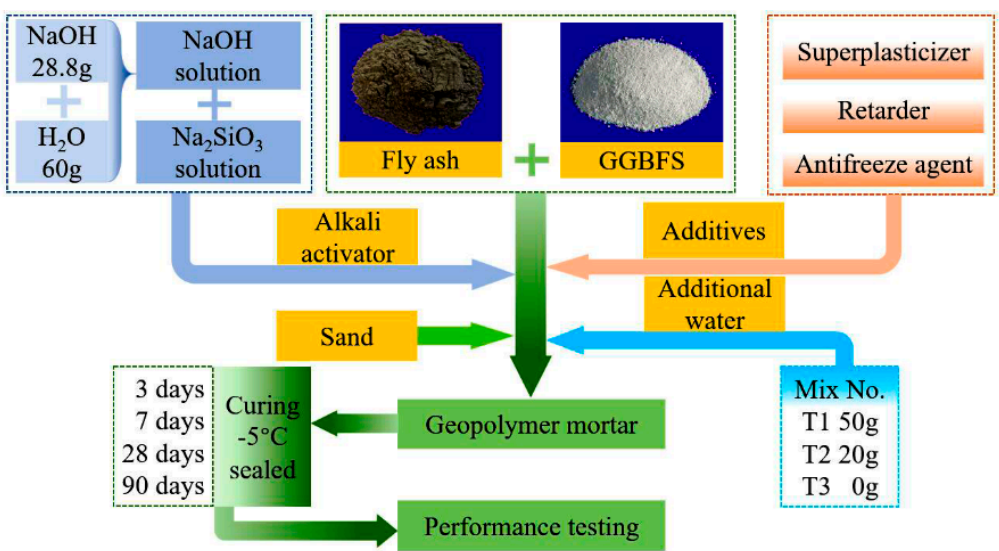

Figure 4. Complete process of samples preparation.

\subsection{Testing Methods}

Three specimens of corresponding ages were taken out from the freezer for uniaxial compressive strength test each time. The uniaxial compressive strength test was carried out on MTS(SANS)-CMT5105 tester (MTS Systems Corporation, Shenzhen, China). The loading rate was set to $0.3 \mathrm{MPa} / \mathrm{s}$ and then loaded until the specimen was destroyed [29]. After the uniaxial compressive strength test, the crushed samples were observed for microstructural characteristics using a Scanning Electron Microscope (SEM, FEI Company, Hillsboro, OR, USA). In addition, some crushed samples were taken out for X-ray diffraction (XRD) test. XRD tests were measured on a Bruker D8 ADVANCE diffractometer (Bruker Corporation, Karlsruhe, Germany), $40 \mathrm{kV}, 40 \mathrm{~mA}$, using $\mathrm{Cu}-\mathrm{K} \alpha$ radiation. The $\mathrm{XRD}$ patterns were recorded within $10^{\circ}-90^{\circ}(2 \theta)$, with a step size $0.01^{\circ}$, and speed of $0.02^{\circ} / \mathrm{s}$.

\section{Experimental Results and Discussion}

\subsection{Compressive Strength}

The compressive strength values of the prepared samples were obtained by uniaxial compression tests. The stress-strain curves of T2 at different ages are plotted in Figure 5. It can be seen that the compressive strength increases and the failure strain decreases gradually with the increasing age. The brittle failure of samples is becoming increasingly evident. T1 and T3 present the same trend, which are not shown repeatedly here. Figure 6 shows the stress-strain curves of each group at age of 7 days. The greater W/B ratio, the lower strength, the failure strain corresponding to peak strength increases gradually, and plastic deformation characteristics become more and more prominent.

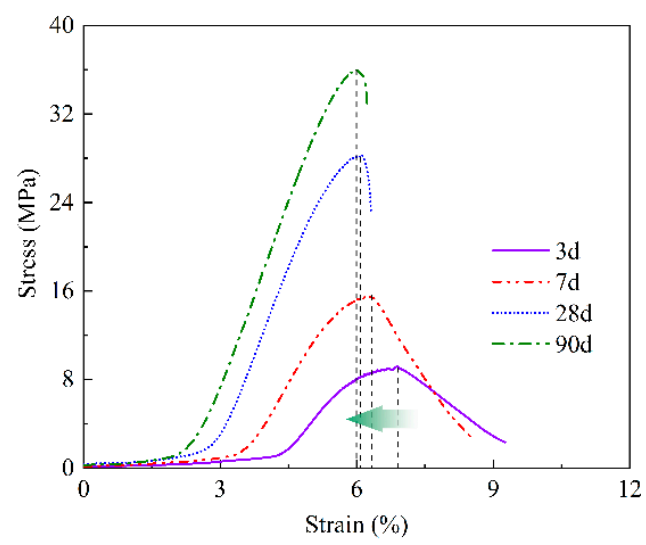

Figure 5. Stress-strain curves of T2 at different ages. 


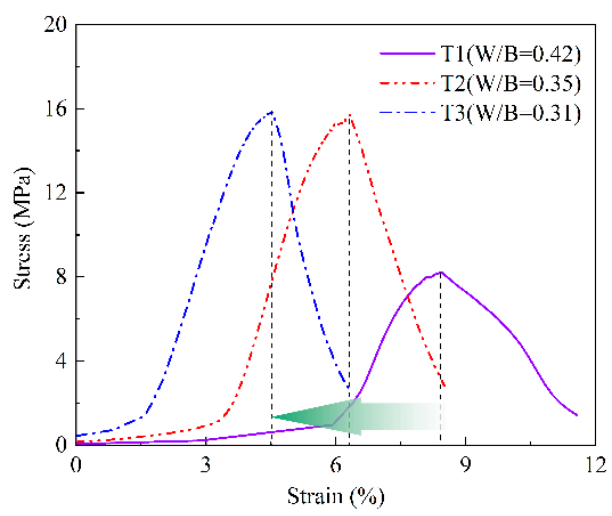

Figure 6. Stress-strain curves of mortars with different Water-to-Binder (W/B) ratios at 7 days.

The compressive strength of mortar samples with different $\mathrm{W} / \mathrm{B}$ ratios was tested at different ages. Three identical samples were tested each time. The mean values are given in Figure 7. It can be seen that the compressive strength of mortar increases gradually with the decrease of W/B ratio at early age $(3 \mathrm{~d}, 7 \mathrm{~d})$. At the age of 3 days and 7 days, the compressive strength increases by $82.13 \%$ and $74.63 \%$, respectively, when the W/B ratio decreases from 0.42 to 0.35 ; when the $\mathrm{W} / \mathrm{B}$ ratio decreases from 0.42 to 0.31 , it increases by $110.23 \%$ and $93.62 \%$, respectively, but when the $\mathrm{W} / \mathrm{B}$ ratio decreases from 0.35 to 0.31 , it increases slightly, $15.43 \%$ and $10.87 \%$, respectively.

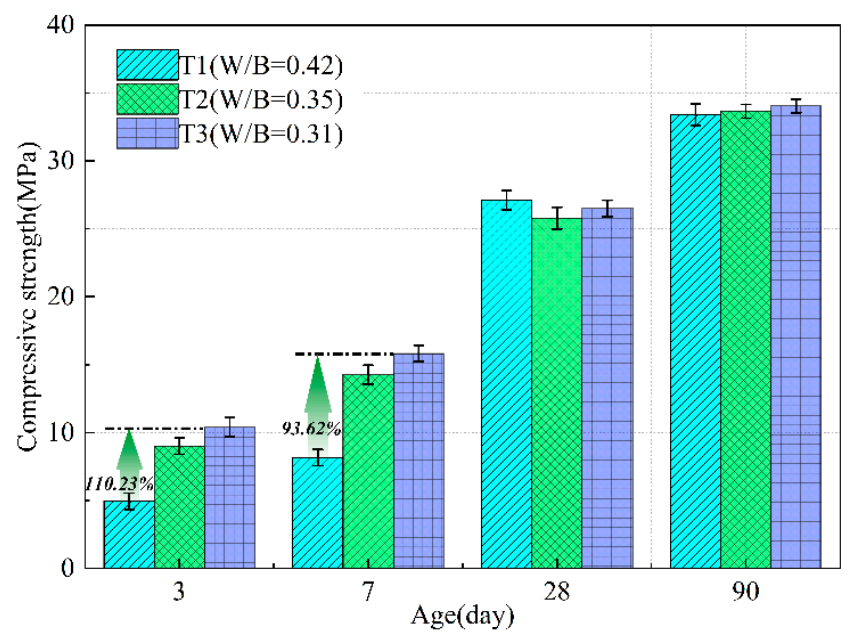

Figure 7. Compressive strengths of mortars with different W/B ratios at different ages.

At the age of 28 days, the compressive strength of each group is basically maintained at the level of 25.78 MPa-27.10 MPa. The compressive strength reached 33.4 MPa-34.04 MPa at the age of 90 days, and the values are very close. It can be concluded that different water content has little influence on long-term strength.

The mechanism of the influence of water content on the strength of geopolymer is discussed based on the above experimental results. It can be clearly observed that, on the prerequisite of satisfying the workability of mortar, reducing the water consumption is beneficial to improving the early strength of mortar under negative temperature conditions. In fact, adding extra different amounts of water has changed the initial molar concentration of $\mathrm{NaOH}$ solution, which is no longer a fixed value of 12 $\mathrm{mol} / \mathrm{L}$, but less than $12 \mathrm{~mol} / \mathrm{L}$. The ultimate concentration of $\mathrm{NaOH}$ solution of $\mathrm{T} 1, \mathrm{~T} 2$, and $\mathrm{T} 3$ was $3.83 \mathrm{~mol} / \mathrm{L}, 4.56 \mathrm{~mol} / \mathrm{L}$, and $5.22 \mathrm{~mol} / \mathrm{L}$, respectively. The higher the water content is, the smaller the molar concentration is. The addition of extra water changes the excitation ability of the activator. Higher initial molar concentration of $\mathrm{NaOH}$ solution promotes the dissolution of aluminosilicate and forms and tetrahedral units in the early age, leading to the augment of strength at the early 
stage [30]. Within a certain range, the increased $\mathrm{NaOH}$ concentration helps to improve the compressive strength of concrete [27,31,32], which is consistent with the results in this paper. However, when the concentration of $\mathrm{NaOH}$ solution exceeds a certain limit, the polycondensation process was hindered and the compressive strength would be reduced $[33,34]$. From the results of this study, the initial concentration of $\mathrm{NaOH}$ solution did not exceed the limit value, and the strength value monotonously increased with the increasing concentration.

Moreover, the mechanism of the influence of water content on the strength of geopolymer is discussed from the reaction equation. Davidovits [4,5] summarized the basic principles of the chemical reactions as follows: Equations (1) and (2):

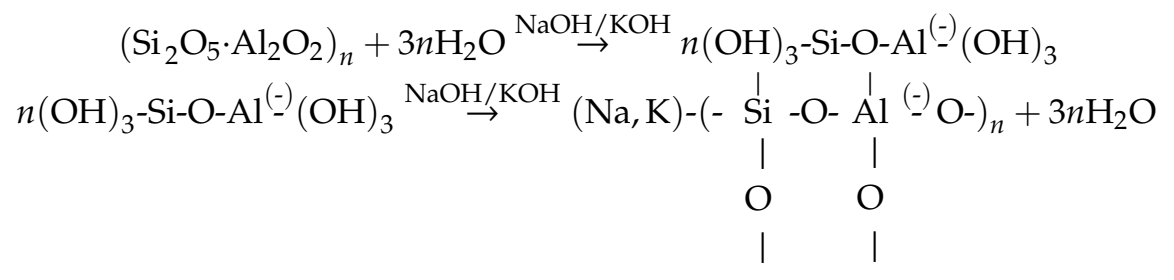

$$
\begin{aligned}
& \left(\mathrm{Si}_{2} \mathrm{O}_{5} \cdot \mathrm{Al}_{2} \mathrm{O}_{2}\right)_{n}+n 2 \mathrm{SiO}_{2}+4 n \mathrm{H}_{2} \mathrm{O} \stackrel{\mathrm{NaOH} / \mathrm{KOH}}{\rightarrow} n(\mathrm{OH})_{3}-\mathrm{Si}-\mathrm{O}-\stackrel{(-)}{\mathrm{Al}}-\mathrm{O}-\mathrm{Si}-(\mathrm{OH})_{3} \\
& (\mathrm{OH})_{2}
\end{aligned}
$$

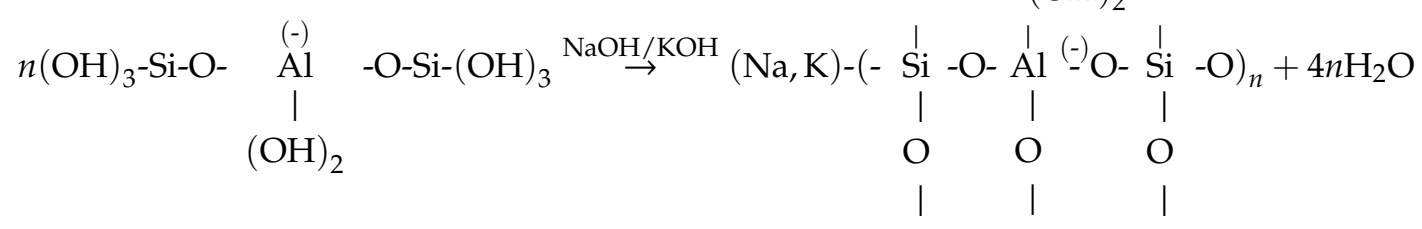

On the one hand, $\mathrm{NaOH}$ is a necessary condition for the reaction. The mass of $\mathrm{NaOH}$ solid particles is constant in the solution, therefore, the final amount of dissolved aluminosilicate is certain and the amount of geopolymer products is certain. On the other hand, it can be seen from the reaction process that the water molecules on the left and right sides of the reaction equation are balanced. Therefore, the study [18] believed that water had no role in the chemical reaction except for providing workability. From the reaction equation alone, the content of water does not affect the amount of geopolymer products. These two aspects are the reason why the long-term strength is very close.

\subsection{Microstructural Properties}

\subsubsection{SEM Observation}

In this section, the influence of water content on the microstructure of geopolymer is discussed. The micrographs of samples have been obtained using SEM as shown in Figure 8a-i. All images clearly show the presence of fly ash cenosphere and slag particles that have completely or partially undergone geopolymer reactions and been embedded in a continuous matrix. The usual trend is that with the same water content, the structure becomes more and more dense for increasing of age. 

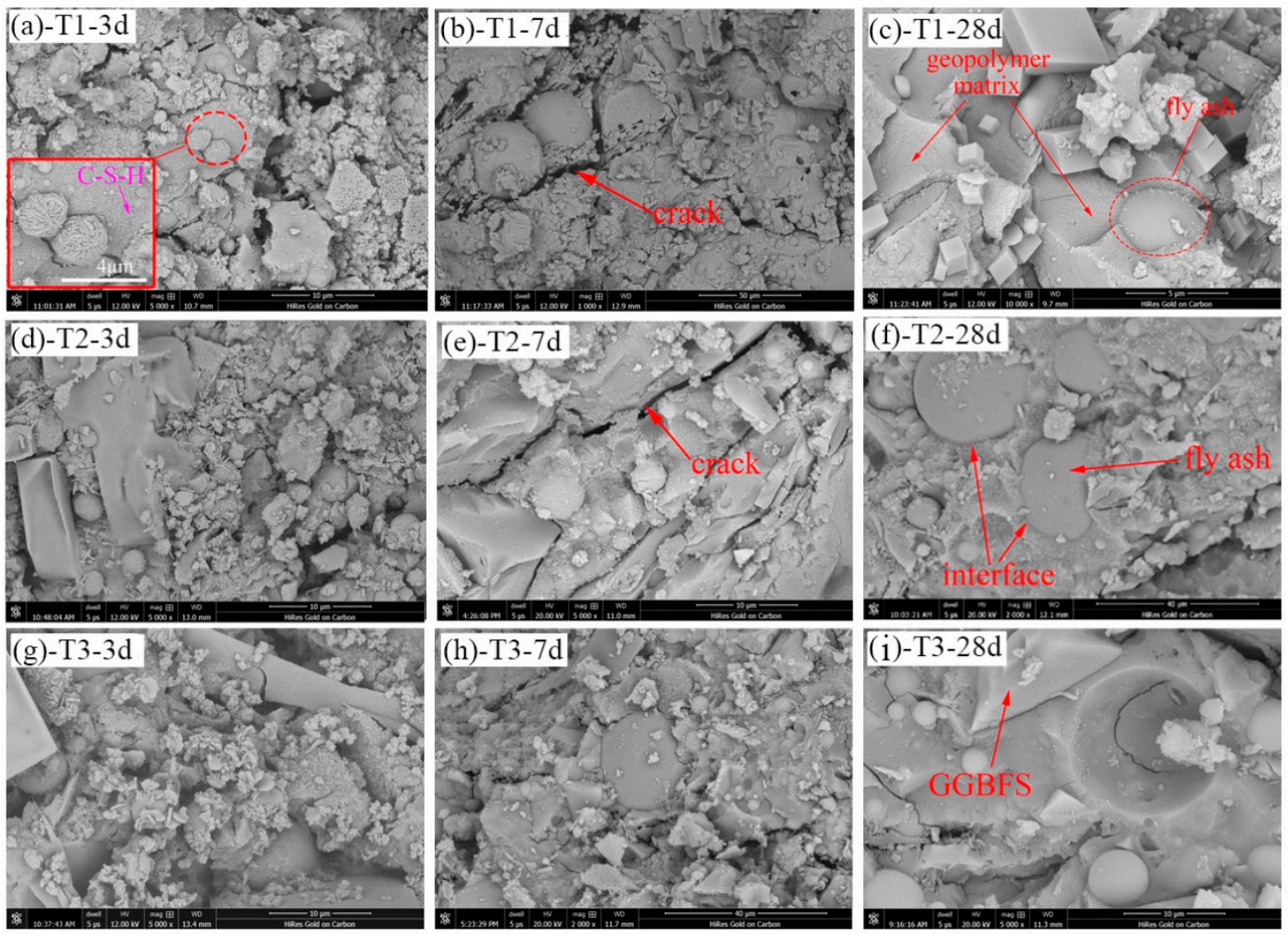

Figure 8. Micrographs of samples at different ages: (a,d,g) 3 days; $(\mathbf{b}, \mathbf{e}, \mathbf{h}) 7$ days; $(\mathbf{c}, \mathbf{f}, \mathbf{i}) 28$ days.

At an age of 3 days, the unreacted fly ash particles in Figure $8 \mathrm{~d}, \mathrm{~g}$ are significantly less than those in Figure 8a. As shown in Figure 8a, after enlarging 10,000 times, the image clearly indicates that the surface of fly ash microspheres is disintegrated and the mullite skeleton is exposed under the excitation of alkaline activator, and the presence of C-S-H gel can also be observed in the diagram. At an age of 7 days, the pores and cracks in Figure 8e,h are obviously less than those in Figure 8b, generating a large number of geopolymer matrix, and the structure shows more compactness. At an age of 28 days, the specimens formed a dense amorphous-gel structure (Figure $8 \mathrm{c}, \mathrm{f}, \mathrm{i}$ ), some unreacted FA and GGBFS particles were still immersed in the gel, the interface between particles and gel is very tight, and there was no difference in the three plots.

It can be concluded that water content has a certain influence on the microstructure of geopolymer in early age. The smaller the water content is, the less unreacted components are, the denser the structure is and the higher the strength is. In addition, the long-term microstructure of geopolymer is not affected by water content. This will explain in terms of microstructure why the geopolymer mortar has low water content but high strength at early age. At the same time, the reason why the strength increases with curing time is explained.

\subsubsection{XRD Analysis}

XRD patterns for all mixtures at different ages are shown in Figure 9a-c. Presence of quartz, lazurite, and amarillite $\left(\mathrm{NaFe}^{3+}\left(\mathrm{SO}_{4}\right)_{2} \cdot 6 \mathrm{H}_{2} \mathrm{O}\right)$ can be observed in all samples and the patterns are quite similar. This shows that different water content only affects the hydration process, and the final hydration products are the same. 


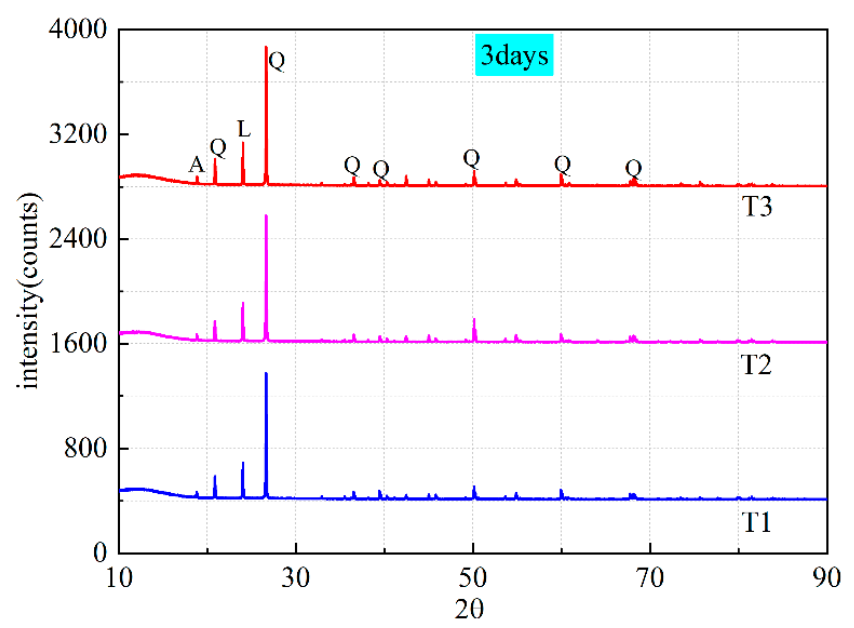

(a)

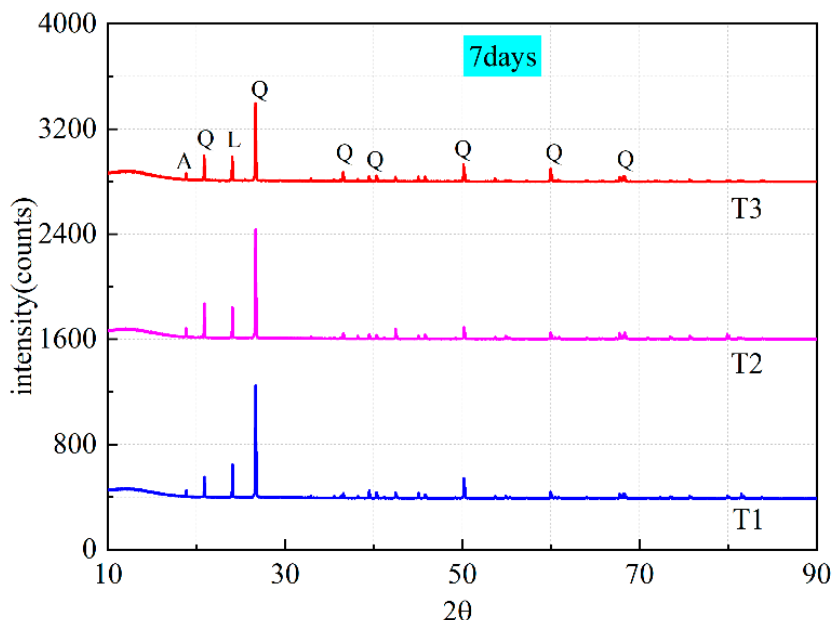

(b)

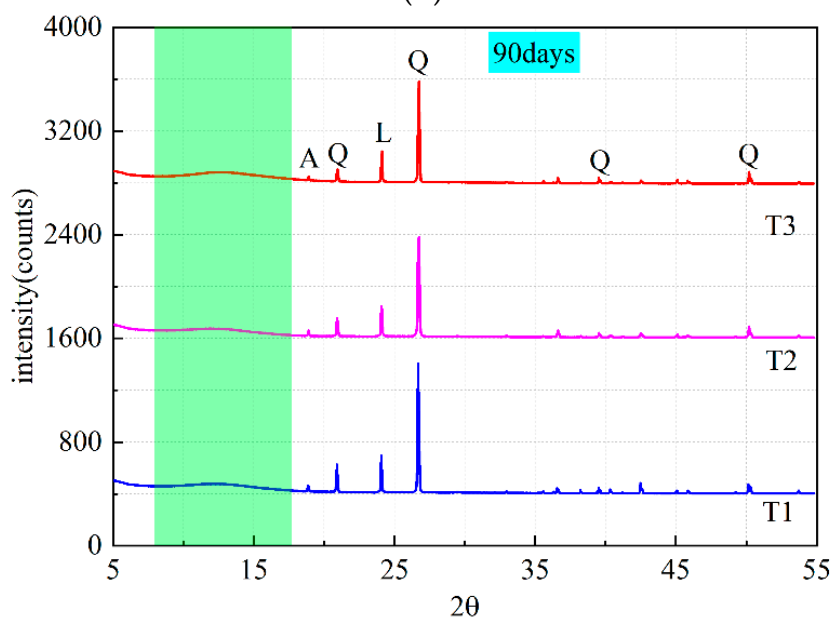

(c)

Figure 9. XRD patterns of samples (T1, T2, T3) at different ages (Q-quartz, A-amarillite, L-lazurite): (a) 3 days; (b) 7 days; (c) 90 days.

The complex composition of lazurite $\left((\mathrm{Na}, \mathrm{Ca}, \mathrm{K})_{7-8} \mathrm{Si}_{6} \mathrm{Al}_{6} \mathrm{O}_{24}\left(\mathrm{SO}_{4}, \mathrm{~S}, \mathrm{Cl}\right) 2 \cdot \mathrm{nH}_{2} \mathrm{O}\right)$ belongs to the sodalite group [35], and the molecular structure indicates the formation of sodium aluminosilicate hydrate(N-A-S-H) gel and calcium aluminosilicate hydrate (C-A-S-H) gel. Sodalite framework is a typical geopolymeric structure [5]. Lazurite mineral crystal has zeolite-like structure. The trisulfur 
$\left(\mathrm{S}^{3-}\right)$ is trapped into a cage of the zeolitic sodalite, which results in the sample manifesting a blue or green color [36,37]. The studies [36,37] showed that the specific color of exterior surface turned to "gray" or "white" when the concrete or mortar contacted with air. This conclusion is proved by the fact that the surface color of the damaged specimen is grey and the interior is green.

A broad hump between $10^{\circ}$ and $20^{\circ}(2 \theta)$ can be observed on the XRD patterns in Figure $9 \mathrm{c}$, which usually represents the existence of amorphous phase. Compared with geopolymer cured at room temperature [38], the hump height is lower. The lower hump height means that the amorphous gel generated by the geopolymerization reaction is less. It can be drawn a conclusion that the curing temperature of geopolymer is an extremely crucial factor. Negative temperature curing reduces the reaction degree of geopolymer.

\subsection{Elasticity Modulus}

The static elastic modulus $\left(E_{c}\right)$ of concrete is a very important performance index in structural design. Generally, the slope of the stress-strain curve at the elastic stage represents the elastic modulus of the material. The compressive strength $\left(f_{c}\right)$ and modulus of elasticity increase with age (Figure 5). It can also be observed in Figure 6, the elastic modulus of T1 is lower than that of T2 and T3, and T2 and $\mathrm{T} 3$ are close to each other. In other words, the modulus of elasticity increases with the decrease of W/B ratio at the same age.

The modulus of elasticity is closely related to compressive strength. Some experimental values and predictive formulas have been given in previous studies on geopolymer [39-42]. Most of the results were acquired from experiments with heat-cured geopolymer concrete. However, no result is currently available for negative temperature cured geopolymer. Therefore, it is essential to explore the prediction model of geopolymer under negative temperature curing. To evaluate the elastic modulus of geopolymer mortar in this study, different existing codes and equations have been proposed, as described below.

American Concrete Institute: According to the ACI Building Code Requirements for Structural Concrete ACI 318-14 [43], elastic modulus of concrete can be calculated by Equation (3):

$$
E_{c}=0.043 \times \rho^{1.5} \times \sqrt{f_{c}^{\prime}}
$$

where $E_{c}$ is the modulus of elasticity; $f_{c}^{\prime}$ is the specified compressive strength (MPa) of concrete after 28 days of curing; $\rho$ is density of concrete ranging from 1442 to $2483 \mathrm{~kg} / \mathrm{m}^{3}$, it takes the measured average value $2404 \mathrm{~kg} / \mathrm{m}^{3}$ in this study; the relationship between the measured compressive strength $f_{c m}$ and $f_{c}^{\prime}$ are given by Equations (4)-(6) [44].

$$
\begin{gathered}
f_{c m}=f_{c}^{\prime}+7.0 \text { for } f_{c}^{\prime} \leq 21 \mathrm{MPa} \\
f_{c m}=f_{c}^{\prime}+8.3 \text { for } 21<f_{c}^{\prime} \leq 35 \mathrm{MPa} \\
f_{c m}=1.1 f_{c}^{\prime}+5.0 \text { for } f_{c}^{\prime}>35 \mathrm{MPa}
\end{gathered}
$$

CEB-FIP Model Code: The elastic modulus of concrete can be estimated by Equation (7) [45].

$$
E_{c}=0.85 \times 2.15 \times 10^{4} \times\left(\frac{f_{c}}{10}\right)^{\frac{1}{3}}
$$

where $f_{c}$ is the mean measured value of compressive strength (MPa).

Hardjito et al. [42]. Recommended a practical formula expressed by Equation (8) to predict elastic modulus of fly ash based geopolymer concrete cured at high temperatures.

$$
E_{c}=2707 \times \sqrt{f_{c}^{\prime}}+5300
$$


In another article [40], Nath and Sarker put forward Equation (9) to predict the elastic modulus of geopolymer concrete cured at room temperature.

$$
E_{c}=3510 \times \sqrt{f_{c}}
$$

Lee and Lee [46] proposed a prediction formula for the elastic modulus of fly ash/slag based geopolymer concrete, as exhibited below.

$$
E_{c}=5300 \times \sqrt[3]{f_{c}}
$$

The values of elastic modulus at different ages $(3 \mathrm{~d}, 7 \mathrm{~d}, 28 \mathrm{~d}, 90 \mathrm{~d})$ for geopolymer mortar were obtained from the stress-strain curves. Each elastic modulus value is the mean of three identical samples with a standard deviation less than $12 \mathrm{MPa}$. The values are drawn in Figure 10 and compared with predicted values using above models. In the figure, both the experimental and predicted values exhibited the general trend of increasing elastic modulus for increasing geopolymer mortar compressive strength. It is clear that, the tests values are lower than any predicted values, the difference is grate. This result is attributed to the applicability of the recommended equations and model codes. The formulas of ACI 318-14 and CEB-FIP code are intended for original Portland concrete (OPC). The equations in references $[40,42,46]$, are applicable to estimate geopolymer concrete cured at elevated temperature or in ambient condition. Moreover, some studies [41,47] have reported that the elastic modulus of OPC is slightly higher than geopolymer concrete. However, in this study, the geopolymer mortar specimens were cured at temperature of $-5^{\circ} \mathrm{C}$, these existing equations are no longer applicable. Based on the analysis of the above formulas and test values, a new empirical model is proposed. The square root form of compressive strength $\left(\sqrt{f_{c}}\right)$ is still used. The least square method is used for regression analysis of data in a given equation, and the ultimate equation is shown as follows.

$$
E_{c}=\alpha \times \sqrt{f_{c}}+\beta
$$

where $f_{c}$ is compressive strength of geopolymer mortar (MPa). Results indicated that the coefficients $\alpha$ and $\beta$ in the model equation are not fixed values, but varying with $\mathrm{W} / \mathrm{B}$ ratios, which are listed in Table 4 and drawn in Figure 11. It can be observed that the coefficients $\alpha$ increases with the increasing of $\mathrm{W} / \mathrm{B}$ ratio, while the coefficient $\beta$ decreases with the increasing of $\mathrm{W} / \mathrm{B}$ ratio. In additional, the correlation coefficient $R$ of different W/B ratios is very high. Hence, Equation (11) is applicable to predict the elastic modulus of geopolymer mortar cured under negative temperature. The coefficients $\alpha$ and $\beta$ can be selected by interpolation according to the $\mathrm{W} / \mathrm{B}$ ratio.

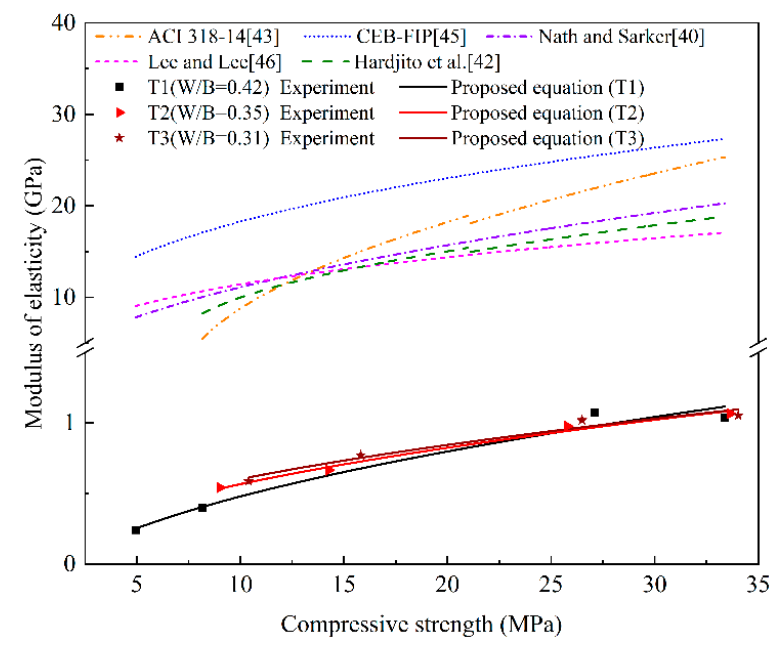

Figure 10. Comparison of tested and predicted results. 
Table 4. Equation Parameters of the empirical Model.

\begin{tabular}{ccccc}
\hline \multirow{2}{*}{ Mix No. } & \multirow{2}{*}{ W/B } & \multicolumn{3}{c}{ Equation (11) } \\
\cline { 3 - 5 } & & $\boldsymbol{\alpha}$ & $\boldsymbol{\beta}$ & $\mathbf{R}$ \\
\hline T1 & 0.42 & 260 & -335 & 0.97 \\
T2 & 0.35 & 197 & -56 & 0.98 \\
T3 & 0.31 & 185 & 18 & 0.96 \\
\hline
\end{tabular}

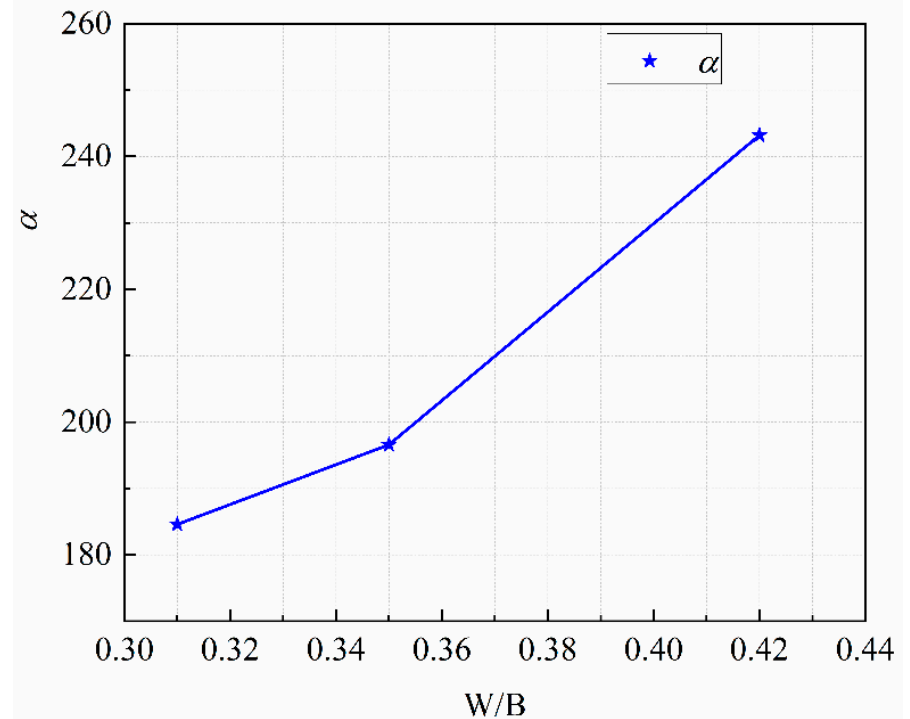

(a)

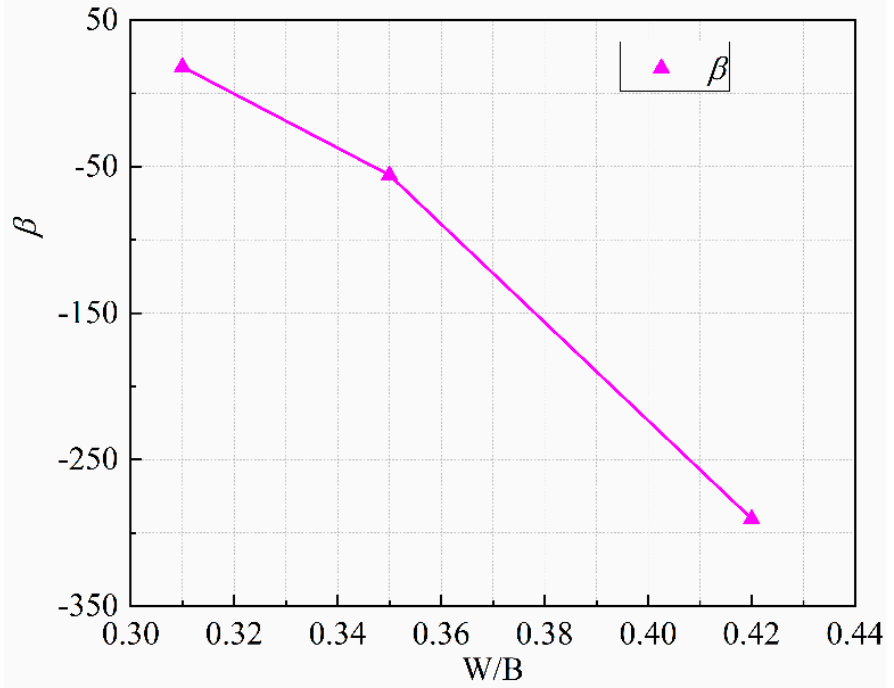

(b)

Figure 11. Variation of coefficients $\alpha$ and $\beta$ with water binder ratio: (a) $\alpha$; (b) $\beta$.

\section{Conclusions}

The influence of water content on the properties of fly ash and GBBFS-based geopolymer mortars cured at $-5{ }^{\circ} \mathrm{C}$ was investigated. Several interesting conclusions can be drawn from the results presented thus far:

(1) Water content has an impact on compressive strength of geopolymer mortar at the age of 3 days and 7 days. At the age of 28 days, the compressive strength of each group is basically maintained at the level of $25.78 \mathrm{MPa}-27.10 \mathrm{MPa}$. The compressive strength reached about 33.4 MPa at the age of 90 days. 
(2) Higher molar concentration of $\mathrm{NaOH}$ solution promotes the dissolution of aluminosilicate in early age, which leads to the increase of strength in early stage. Lower water content is beneficial to improving the early strength of mortar under negative temperature conditions, however, water content has little effect on long-term strength.

(3) An empirical model is proposed to predict $E_{c}$, which exhibited better applicability for geopolymer mortar cured at temperature of $-5{ }^{\circ} \mathrm{C}$. The change of water content affects the coefficients in the model.

Author Contributions: Conceptualization, X.W. and F.M.; methodology, X.W.; formal analysis, X.W.; data curation, X.W.; writing - original draft preparation, X.W.; funding acquisition, F.M.; writing-review and editing F.M., D.L., L.C., and Y.L. All authors have read and agreed to the published version of the manuscript.

Funding: This research was funded by the National Natural Science Foundation of China, grant number 41701060; It also was funded by the funding of Key Research Program of Frontier Science of Chinese Academy of Sciences (QYZDY-SSW-DQC015) and the funding of the State Key Laboratory of Frozen Soil Engineering, Grant number. SKLFSEZT17.

Acknowledgments: The authors wish to gratefully acknowledge the support of Cold and Arid Regions Environmental and Engineering Research Institute, Chinese Academy of Sciences. The help of State Key Laboratory of Frozen Soil Engineering staffs is gratefully acknowledged.

Conflicts of Interest: The authors declare no conflict of interest.

\section{References}

1. Gartner, E. Industrially interesting approaches to "low- $\mathrm{CO}_{2}$ " cements. Cem. Concr. Res. 2004, 34, $1489-1498$. [CrossRef]

2. Meyer, C. The greening of the concrete industry. Cem. Concr. Compos. 2009, 31, 601-605. [CrossRef]

3. Singh, N. Fly Ash-Based Geopolymer Binder: A Future Construction Material. Minerals 2018, 8, 299. [CrossRef]

4. Davidovits, J. Geopolymers-Inorganic Polymeric New Materials. J. Therm. Anal. 1991, 37, $1633-1656$. [CrossRef]

5. Davidovits, J. Geopolymers and Geopolymeric Materials. J. Therm. Anal. 1989, 35, 429-441. [CrossRef]

6. Singh, B.; Ishwarya, G.; Gupta, M.; Bhattacharyya, S.K. Geopolymer concrete: A review of some recent developments. Constr. Build. Mater. 2015, 85, 78-90. [CrossRef]

7. Maddalena, R.; Roberts, J.J.; Hamilton, A. Can Portland cement be replaced by low-carbon alternative materials? A study on the thermal properties and carbon emissions of innovative cements. J. Clean. Prod. 2018, 186, 933-942. [CrossRef]

8. Okoye, F.N. Geopolymer binder: A veritable alternative to Portland cement. Mater. Today Proc. 2017, 4, 5599-5604. [CrossRef]

9. Aslani, F.; Asif, Z. Properties of Ambient-Cured Normal and Heavyweight Geopolymer Concrete Exposed to High Temperatures. Materials 2019, 12, 740. [CrossRef]

10. Li, X.; Ma, X.; Zhang, S.; Zheng, E. Mechanical Properties and Microstructure of Class C Fly Ash-Based Geopolymer Paste and Mortar. Materials 2013, 6, 1485-1495. [CrossRef]

11. Valizadeh, A.; Aslani, F.; Asif, Z.; Roso, M. Development of Heavyweight Self-Compacting Concrete and Ambient-Cured Heavyweight Geopolymer Concrete Using Magnetite Aggregates. Materials 2019, 12, 1035. [CrossRef] [PubMed]

12. Farhad Aslani, M.A.; Deghani, A.; Asif, Z. Development of lightweight rubberized geopolymer concrete by using polystyrene and recycled crumb-rubber aggregates. J. Mater. Civ. Eng. 2019, 32. [CrossRef]

13. Neupane, K.; Kidd, P.; Chalmers, D.; Baweja, D.; Shrestha, R. Investigation on compressive strength development and drying shrinkage of ambient cured powder-activated geopolymer concretes. Aust. J. Civ. Eng. 2016, 14, 72-83. [CrossRef]

14. Oh, J.E.; Monteiro, P.J.M.; Jun, S.S.; Choi, S.; Clark, S.M. The evolution of strength and crystalline phases for alkali-activated ground blast furnace slag and fly ash-based geopolymers. Cem. Concr. Res. 2010, 40, 189-196. [CrossRef] 
15. Albitar, M.; Ali, M.S.M.; Visintin, P.; Drechsler, M. Effect of granulated lead smelter slag on strength of fly ash-based geopolymer concrete. Constr. Build. Mater. 2015, 83, 128-135. [CrossRef]

16. Data Center of Resources and Environment Science, Chinese Academy of Sciences. Available online: http://www.resdc.cn/ (accessed on 10 October 2019).

17. Weng, L.; Sagoe-Crentsil, K. Dissolution processes, hydrolysis and condensation reactions during geopolymer synthesis: Part I-Low Si/Al ratio systems. J. Mater. Sci. 2007, 42, 2997-3006. [CrossRef]

18. Aliabdo, A.A.; Abd Elmoaty, A.E.M.; Salem, H.A. Effect of water addition, plasticizer and alkaline solution constitution on fly ash based geopolymer concrete performance. Constr. Build. Mater. 2016, 121, 694-703. [CrossRef]

19. Chindaprasirt, P.; Chareerat, T.; Sirivivatnanon, V. Workability and strength of coarse high calcium fly ash geopolymer. Cem. Concr. Compos. 2007, 29, 224-229. [CrossRef]

20. Xie, J.; Kayali, O. Effect of initial water content and curing moisture conditions on the development of fly ash-based geopolymers in heat and ambient temperature. Constr. Build. Mater. 2014, 67, 20-28. [CrossRef]

21. Shubbar, A.A.; Jafer, H.; Dulaimi, A.; Hashim, K.; Atherton, W.; Sadique, M. The development of a low carbon binder produced from the ternary blending of cement, ground granulated blast furnace slag and high calcium fly ash: An experimental and statistical approach. Constr. Build. Mater. 2018, 187, 1051-1060. [CrossRef]

22. Nowoswiat, A.; Golaszewski, J. Influence of the Variability of Calcareous Fly Ash Properties on Rheological Properties of Fresh Mortar with Its Addition. Materials 2019, 12, 1942. [CrossRef] [PubMed]

23. Velandia, D.F.; Lynsdale, C.J.; Provis, J.L.; Ramirez, F. Effect of mix design inputs, curing and compressive strength on the durability of Na2SO4-activated high volume fly ash concretes. Cem. Concr. Compos. 2018, 91, 11-20. [CrossRef]

24. van Jaarsveld, J.G.S.; van Deventer, J.S.J. Effect of the alkali metal activator on the properties of fly ash-based geopolymers. Ind. Eng. Chem. Res. 1999, 38, 3932-3941. [CrossRef]

25. Zhang, B.; MacKenzie, K.J.D.; Brown, I.W.M. Crystalline phase formation in metakaolinite geopolymers activated with $\mathrm{NaOH}$ and sodium silicate. J. Mater. Sci. 2009, 44, 4668-4676. [CrossRef]

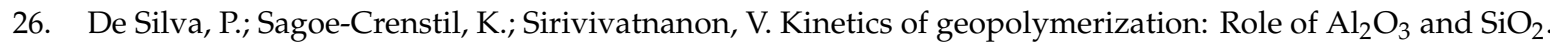
Cem. Concr. Res. 2007, 37, 512-518. [CrossRef]

27. Görhan, G.; Kürklü, G. The influence of the $\mathrm{NaOH}$ solution on the properties of the fly ash-based geopolymer mortar cured at different temperatures. Compos. Part B Eng. 2014, 58, 371-377. [CrossRef]

28. Neupane, K. Fly ash and GGBFS based powder-activated geopolymer binders: A viable sustainable alternative of portland cement in concrete industry. Mech. Mater. 2016, 103, 110-122. [CrossRef]

29. Ministry of Construction of the People's Republic of China. Standard for Test Method of Performance on Building Mortar; China Architecture \& Building Press: Beijing, China, 1991.

30. Lee, W.-H.; Wang, J.-H.; Ding, Y.-C.; Cheng, T.-W. A study on the characteristics and microstructures of GGBS/FA based geopolymer paste and concrete. Constr. Build. Mater. 2019, 211, 807-813. [CrossRef]

31. Somna, K.; Jaturapitakkul, C.; Kajitvichyanukul, P.; Chindaprasirt, P. NaOH-activated ground fly ash geopolymer cured at ambient temperature. Fuel 2011, 90, 2118-2124. [CrossRef]

32. Rattanasak, U.; Chindaprasirt, P. Influence of $\mathrm{NaOH}$ solution on the synthesis of fly ash geopolymer. Miner. Eng. 2009, 22, 1073-1078. [CrossRef]

33. Lee, W.K.W.; van Deventer, J.S.J. The effects of inorganic salt contamination on the strength and durability of geopolymers. Colloid Surf. A Phsicochem. Eng. Asp. 2002, 211, 115-126. [CrossRef]

34. Zuhua, Z.; Xiao, Y.; Huajun, Z.; Yue, C. Role of water in the synthesis of calcined kaolin-based geopolymer. Appl. Clay Sci. 2009, 43, 218-223. [CrossRef]

35. Rastsvetaeva, R.K.; Bolotina, N.B.; Sapozhnikov, A.N.; Kashaev, A.A.; Schoenleber, A.; Chapuis, G. Average structure of cubic lazurite with a three-dimensional incommensurate modulation. Crystallogr. Rep. 2002, 47, 404-407. [CrossRef]

36. Reinen, D.; Lindner, G.-G. The nature of the chalcogen colour centres in ultramarine-type solids. Chem. Soc. Rev. 1999, 28, 75-84. [CrossRef]

37. Chaouche, M.; Gao, X.X.; Cyr, M.; Cotte, M.; Frouin, L. On the origin of the blue/green color of blast-furnace slag-based materials: Sulfur K-edge XANES investigation. J. Am. Ceram. Soc. 2017, 100, 1707-1716. [CrossRef] 
38. Xu, H.; Gong, W.; Syltebo, L.; Izzo, K.; Lutze, W.; Pegg, I.L. Effect of blast furnace slag grades on fly ash based geopolymer waste forms. Fuel 2014, 133, 332-340. [CrossRef]

39. Cao, Y.-F.; Tao, Z.; Pan, Z.; Wuhrer, R. Effect of calcium aluminate cement on geopolymer concrete cured at ambient temperature. Constr. Build. Mater. 2018, 191, 242-252. [CrossRef]

40. Nath, P.; Sarker, P.K. Flexural strength and elastic modulus of ambient-cured blended low-calcium fly ash geopolymer concrete. Constr. Build. Mater. 2017, 130, 22-31. [CrossRef]

41. Fernandez-Jimenez, A.M.; Palomo, A.; Lopez-Hombrados, C. Engineering properties of alkali-activated fly ash concrete. ACI Mater. J. 2006, 103, 106-112.

42. Hardjito, D.; Wallah, S.E.; Sumajouw, D.M.J.; Rangan, B.V. On the development of fly ash-based geopolymer concrete. ACI Mater. J. 2004, 101, 467-472.

43. American Concrete Institute. Building Code Requirements for Structural Concrete and Commentary; American Concrete Institute: Farmington Hills, MI, USA, 2014.

44. American Concrete Institute. Guide to Evaluation of Strength Test Results of Concrete; American Concrete Institute: Farmington Hills, MI, USA, 2011.

45. Comite Euro-International Du Beton. CEB-FIP Model Code; Comite Euro-International Du Beton: Telford, UK, 1990.

46. Lee, N.K.; Lee, H.K. Setting and mechanical properties of alkali-activated fly ash/slag concrete manufactured at room temperature. Constr. Build. Mater. 2013, 47, 1201-1209. [CrossRef]

47. Sofi, M.; van Deventer, J.S.J.; Mendis, P.A.; Lukey, G.C. Engineering properties of inorganic polymer concretes (IPCs). Cem. Concr. Res. 2007, 37, 251-257. [CrossRef]

(C) 2019 by the authors. Licensee MDPI, Basel, Switzerland. This article is an open access article distributed under the terms and conditions of the Creative Commons Attribution (CC BY) license (http://creativecommons.org/licenses/by/4.0/). 